\title{
Workshop
}

\section{The Growing Involvement of Horticulture in eXtension: Updates and Opportunities. An Introduction to the Proceedings}

\author{
Richard E. Durham ${ }^{1}$
}

AdDitionAl InDEX words. apple, grape, Extension Master Gardeners, integrated pest management, organic production

$\mathrm{T}$ The national eXtension Initiative officially launched its public web site on 21 Feb. 2008 at the U.S. Department of Agriculture, Agriculture Outlook Forum in Washington, DC. Work on this initiative has been ongoing for several years. In 2005, eight communities of practice (CoPs) were funded to begin identifying and/or developing content for eXtension. Among these pioneer CoPs was one devoted to consumer horticulture that participated in the public launch using a more userfriendly identity of Gardens, Lawns and Landscapes. In the last few years, additional horticulture-themed CoPs have been developed, including All About Blueberries, Apple Rootstocks and Cultivars, and Grapes. Other, broader in scope CoPs exist that relate to horticulture including Bee Health, eOrganic, Plant Breeding and Genomics, Wildlife Damage Management, and others. The topic of eXtension has been the subject of

Extension Professor, Department of Horticulture, University of Kentucky, Lexington, KY 40546-0091

This paper was part of the workshop "The Growing Involvement of Horticulture in eXtension: Updates and Opportunities" held 27 Sept. 2011 at the ASHS Conference, Waikoloa, HI, and sponsored by the eXtension (EEXT) Working Group.

${ }^{1}$ Corresponding author. E-mail: rdurham@uky.edu. several recent workshops at ASHS conferences. In 2010 the ASHS eXtension (EEXT) Working Group was formed and led to sponsoring of the 2011 eXtension workshop and these proceedings.

What follows are five papers that discuss various aspects of forming, managing, evaluating, and funding eXtension CoPs. Two papers, authored by Hoover et al. (2012) and Stafne et al. (2012), provide insight into the development of relatively new CoPs focused on apple (Malus sp.) and grape (Vitis sp.) production. The apple CoP benefits from an established network of extension staff and researchers across the United States who have been working collaboratively on cultivar and rootstock evaluations for several years. However, much of the data generated by this collaboration is not readily available to extension staff, consultants, producers, and consumers. One goal of the apple CoP is to translate this data into more user-friendly forms and make it broadly available to apple producers and consumers through online technology available at eXtension. The objectives of the grape CoP are similar but this community grew from the National Grape and Wine Initiative (NGWI), a coalition of the grape industry. The NGWI charged its extension/outreach committee to ensure that information from various aspects of grape research be available to industry members. The paper describes how involvement of the NGWI was instrumental in securing funding for establishing the grape $\mathrm{CoP}$ and how this industry involvement remains crucial in sustaining the CoP's work.

The paper by Stone et al. (2012) describes eOrganic, the eXtension CoP for organic production. eOrganic encompasses both animal and plant production agriculture and so reaches beyond the topic of horticulture. However, a significant body of eOrganic content relates to organic production of horticultural crops. eOrganic was initiated in 2007 and its content was made publically available in early 2009 . Therefore, eOrganic is moving beyond the initial phase of forming their $\mathrm{CoP}$ and can now share information about how their $\mathrm{CoP}$ is managed, how content and outreach activities are evaluated, and how their $\mathrm{CoP}$ is sustained.

The remaining two papers discuss a specific product of an eXtension CoP (Meyer et al., 2012) and how a specific eXtension tool has been used to address a need of answering home horticulture questions (Durham and Harker, 2012). The Meyer et al. (2012) paper describes the development and use of an online diagnostic module for educating Extension Master Gardeners. This project was initiated as a user-generated CoP in eXtension (North Central Consumer Horticulture Working Group), whereby a group of extension or related personnel can form their own $\mathrm{CoP}$ and make use of eXtension tools in building content. Their example is but one of many such CoPs that form from a community that works on a common problem, objective, or opportunity. The paper of Durham and Harker (2012) details the growth of the eXtension "Ask an Expert" application within the Consumer Horticulture CoP. This paper details the work of a few states at initiating the program, the inclusion of Extension Master Gardeners as experts in the system, and how the growth in institutionalization of eXtension into the land-grant system has increased involvement in this application nationwide.

Collectively, these papers provide evidence of involvement, indeed 
a growing involvement, of horticulture in eXtension. With the formation of the ASHS EEXT working group, along with ongoing activity of the other extension working groups of consumer horticulture/master gardener and commercial horticulture, ASHS and particularly HortTechnology, should provide a venue for reporting of horticulture-themed eXtension activity.

\section{Literature cited}

Durham, R.E. and C. Harker. 2012. Multistate efforts to answer consumer horticulture questions in eXtension. HortTechnology 22:592-593.
Hoover, E.E., R.P. Marini, E. Tepe, W.E. Autio, A.R. Biggs, J.M. Clements, R.M. Crassweller, D.D. Foster, M.J. Foster, P.M. Hirst, D.D. Miller, M.L. Parker, G.M. Peck, J. Racsko, T.L. Robinson, and M.R. Warmund. 2012. eApples: A case study in using eXtension to increase access to research-based information. HortTechnology 22:576579 .

Meyer, M.H., C. Haynes, D. Ellsworth, S.E. Williams, C. Welty, and K. Jeannette. 2012. An online plant diagnostics module for Extension Master Gardeners. HortTechnology 22:589-591.
Stafne, E.T., E.W. Hellman, R.K. Striegler, J.A. Wolpert, and J.-M. Peltier. 2012. Industry involvement in the creation and funding of the eXtension grape community of practice. HortTechnology 22:580-582.

Stone, A.G., D.D. Tredwell, A.K. Formiga, J.P.G. McQueen, M.M. Wander, J. Riddle, H.M. Darby, and D. Heleba. 2012. eOrganic: The organic agriculture community of practice for eXtension. HortTechnology 22:583-588. 